\title{
KEBIJAKAN POLITIK HUKUM PENANGANAN COVID-19 DALAM PERSPEKTIF MAQASHID AL-SYARI'AH
}

\author{
Imaro Sidqi ${ }^{1}$, Doli Witro ${ }^{2}$ \\ ${ }^{1}$ Institut Agama Islam Negeri Pekalongan, ${ }^{2}$ UIN Sunan Gunung Djati Bandung \\ Email: ${ }^{\text {imarosidqi@gmail.com, }}{ }^{2}$ doliwitro01@gmail.com
}

\begin{abstract}
Abstrak
Coronavirus Disease 2019 (covid-19) merupakan penyakit yang sangat berbahaya, ditandai dengan penularannya yang sangat mudah. Dalam penanganannya, pemerintah berlandaskan Undang-Undang Nomor 6 Tahun 2018 tentang Kekarantinaan Kesehatan dan Perppu Nomor 23 tahun 1959 Tentang Pencabutan Undang-Undang Nomor 74 Tahun 1957 Tentang Keadaan Bahaya yang kemudian menurunkan kebijakan PSBB dan new normal serta kebijakan-kebijakan yang lainnya dalam lingkup yang sama. Kebijakan tersebut masih dinilai kurang baik dihadapan masyarakat, karena penerapannya yang kurang efektif dan masih ditunggangi kepentingan-kepentingan lain. Penelitian ini menggunakan kajian normatif dengan pendekatan filosofis, yuridis, dan sosiologis. Pro dan kontra atas kebijakan-kebijakan yang ditempuh merupakan hak yang wajar, pro karena kebijakannya sudah menjadi kebijakan yang cepat dan tanggap, di sisi yang kontra kebijakan yang diterapkan tidak efektif dengan melihat angka covid-19 yang masih terbilang tinggi. Akan tetapi, pada dasarnya kebijakan yang ditempuh oleh pemerintah tidak selalu berjalan dengan sempurna, namun di sisi lain kebijakan yang selama ditempuh dianggap merupakan keputusan terbaik dengan memprioritaskan hak-hak rakyat, hak-hak itulah yang telah tercermin dalam bingkai maqashid al-syariah baik hak-hak beragama, hak hidup, hak memperoleh informasi yang benar, hak keturunan serta hak dalam memenuhi kebutuhan hidup yang diaktualkan ke dalam rumusan kebijakan-kebijakan yang diatur dalam penanganan Covid-19.
\end{abstract}

Kata Kunci: Covid-19, Kebijakan PSBB, New Normal, Maqashid Al-Syariah

\begin{abstract}
Coronavirus Disease 2019 (covid-19) is a very dangerous disease, characterized by very easy transmission. In handling it, the government is based on Law Number 6 of 2018 concerning Health Quarantine and Perppu Number 23 of 1959 concerning the Revocation of Law Number 74 of 1957 concerning Hazard Conditions which subsequently lowered the PSBB and new normal policies and other policies within the scope of same. This policy is still considered to be unfavorable in front of the public, due to its ineffective implementation and other interests. This study uses a normative study with a philosophical, juridical, and sociological approach. The pros and cons of the policies pursued are reasonable rights, pros because the policies have become fast and responsive policies, on the other hand, the policies implemented are ineffective considering the covid-19 figure which is still relatively high. However, basically, the policies adopted by the government do not always run perfectly, but on the other hand, the policies that have been taken are considered to be the best decisions by prioritizing people's rights, those rights that have been reflected in the framework of maqashid al-sharia, both rights. - religious rights, the right to life, the right to obtain correct information, the right of descent, and the right to fulfill the necessities of life which are actualized in the formulation of policies regulated in handling Covid-19.
\end{abstract}

Keywords: Covid-19, PSBB, New Normal Policy, Maqashid Al-Syariah 



\section{A.PENDAHULUAN}

Ada perbedaan yang sangat besar di tahun ini dengan tahun sebelumnya, di mana di tahun-tahun sebelumnya hanya beberapa rentetan fakta yang biasa terjadi seperti isu politik, ekonomi, ataupun yang lainnya. Namun di tahun ini, ada kejadian fakta yang sangat tidak disangka secara tidak logis oleh pikiran manusia yakni hadirnya coronavirus disease 2019 (Covid-19). Hadirnya covid-19 ${ }^{1}$ ini membawa perubahan yang sangat besar baik perubahan dalam sektor ekonomi, sosial, maupun sektor-sektor yang lainnya.

Diawali dari China yang kemudian menular sampai ke 150 negara di dunia, termasuk adalah Indonesia. ${ }^{2}$ World Health Organization (WHO) menyatakan Covid19 sebagai pandemic global, dikarenakan penyebarannya yang sangat signifikan. Dibuktikan dengan data dari WHO menyatakan bahwa angka Covid-19 di dunia telah mencapai 59,4 juta kasus, dengan rincian 38 juta sembuh dan sebanyak 1,4 juta dinyatakan meninggal dunia. Sementara itu, di Indonesia sendiri yang terjerat positif virus Covid-19 sebanyak 506.302, dengan rincian sembuh 425.313, dan 16.111 dinyatakan meninggal dunia yang telah menyebar di seluruh penjuru Indonesia dengan estimasi paling banyak berada di DKI Jakarta. ${ }^{3}$

Keadaan tersebut tentunya memaksa pemerintah sebagai policy maker

${ }^{1}$ Coronavirus merupakan penyakit yang dapa menyebabkan gejala-gejala seperti penyakit pada umumnya, dimulai dari yang ringan-berat. Penyakit yang sejenis adalah Sars dan Mers. Penyebaran virus corona antar manusia atau antar makhluk hidup yang lain sangat mudah sekali, sehingga perlu kehati-hatian. Kementerian Kesehatan RI, Pedoman Pencegahan Dan Pengendalian Coronavirus Disease (Covid-19) (Jakarta: Kemenkes RI, 2020), 11.

${ }^{2}$ Lutfi Fahrul Rizal, "Persfektif Siyâsah Syar'Iyyah Tentang Darurat Negara Dalam Penanganan Pandemi Covid-19," ADLIYA: Jurnal Hukum Dan Kemanusiaan 14, no. 1 (2020): 42, https://doi.org/10.15575/adliya.v14i1.8404.

3 Covid19.go.id, "Data Sebaran," 2020, https://covid19.go.id/. (pembuat kebijakan) untuk segera merespon dengan cerdas agar penanganan dapat dilakukan secara efektif dan efisien. Kebijakan yang dimaksud merupakan kebijakan bersama antara presiden sebagai kepala pemerintahan sekaligus kepala negara dengan Dewan Perwakilan Rakyat (DPR) sebagai pembuat Undang-Undang, keduanya saling shared responsibility (berbagi tanggungjawab) untuk melindungi seluruh warga negara Indonesia yang sangat luas ini sebagaimana yang telah diatur dalam konstitusi negara ${ }^{4}$. Adapun yang harus dilindungi dalam hal ini merupakan hak hidup, hak rasa aman, serta hak kesehatan masyarakat. ${ }^{5}$ Maka dari itu, kebijakan yang cepat dan tepat sangat dibutuhkan sekali saat ini. $^{6}$

Kebijakan yang sigap dari pemerintah terlihat pada kasus 2 orang yang pertama kali terjangkit virus pada tanggal 2 maret 2020. Presiden memerintahkan kedutaan China untuk memberikan perhatian yang lebih terhadap WNI yang ada disana, selain itu Presiden menyiapkan 100 rumah sakit untuk bersiaga ketika penularan Covid-19 semakin berkembang, serta Presiden memasang setiap bandara dan pelabuhan agar seluruh masyarakat dari luar negeri untuk dicek status Covid-19-nya. ${ }^{7}$ Kemudian setelah terjadinya banyak penularan, pemerintah mengeluarkan aturan khusus untuk penanggulangan bencana Covid-19 ini.

Penanggulangan yang dilakukan oleh pemerintah dengan menggunakan

${ }^{4}$ Undang-Undang Dasar Negara Republik Indonesia Tahun 1945.

5 Pasal 28 Undang-Undang Dasar Negara Republik Indonesia Tahun 1945.

6 Rizal, "Persfektif Siyâsah Syar'Iyyah Tentang Darurat Negara Dalam Penanganan Pandemi Covid-19," 43.

7 Kompas.id, "Upaya Dan Kebijakan Pemerintah Indonesia Menangani Pandemi Covid19," 2020 , https://kompaspedia.kompas.id/baca/paparantopik/upaya-dan-kebijakan-pemerintah-indonesiamenangani-pandemi-covid-19. 
Undang-Undang Nomor 6 Tahun 2018 tentang Kekarantinaan Kesehatan dan Perppu Nomor 23 tahun 1959 Tentang Pencabutan Undang-Undang Nomor 74 Tahun 1957 Tentang Keadaan Bahaya sebagai aturan dasarnya yang kemudian dibentuk aturan-aturan khusus di bawahnya. Tujuan aturan-aturan tersebut tentunya untuk menjamin perlindungan masyarakat secara luas dari berbagai aspek baik keselamatan warga negaranya, stabilitas ekonomi, politik, hukum, serta lainnya. ${ }^{8}$

Rentetan kebijakan di atas membawa perhatian yang besar bagi masyarakat, kebijakan-kebijakan tersebut masih dinilai kurang efektif dalam penanganan pandemi ini, sebagian menganggap bahwa pemerintah slow respon terhadap kondisi ini, bahwa sebagian yang lainnya lagi menganggap pemerintah hanya mementingkan pihakpihak tertentu saja dalam penanganan Covid-19 ini. Sebagaimana contohnya kritikan dari ILUNI (Ikatan Alumni Universitas Indonesia) menganggap bahwa pemerintah selama ini tidak efektif dalam menangani kasus-kasus covid-19. ${ }^{9}$ Akan tetapi, pada dasarnya kebijakan yang ditempuh oleh pemerintah tidak selalu berjalan dengan sempurna, namun di sisi lain kebijakan yang selama ditempuh dianggap merupakan keputusan terbaik dengan memprioritaskan hak-hak rakyat, hak-hak itulah yang telah tercermin dalam bingkai maqashid al-syariah.

Ada beberapa penelitian sebelumnya yang membahas tentang kebijakan penanganan Covid-19 dalam pandangan maqashid al-syari'ah, di antaranya ialah Hudzaifah Achmad

8 Rizal, "Persfektif Siyâsah Syar'Iyyah Tentang Darurat Negara Dalam Penanganan Pandemi Covid-19," 43.

${ }^{9}$ Cnbcindonesia.com, "Kasus COVID-19 Meningkat, Ini Desakan ILUNI UI Ke Pemerintah," 2020, https://www.cnbcindonesia.com/news/2020110711 4532-4-200050/kasus-covid-19-meningkat-inidesakan-iluni-ui-ke-pemerintah.
Qotadah $^{10}$, Shubhan Shodiq ${ }^{11}$, dan Lutfi Fahrul Rizal ${ }^{12}$. Berangkat dari beberapa penelitian tersebut, secara khusus belum ada yang membahas secara lebih lengkap dan luas terkait kebijakan-kebijakan yang ditempuh oleh pemerintah. Kebijakan yang dimaksud oleh Hudzaifah Achmad Qotadah terbatas pada ibadah penanggungan shalat di tempat ibadah. Pada penelitian Subhan Shodiq membahas kebijakan PSBB saja, tidak secara lengkap dengan kebijakan new normal yang barubaru ini. Sementara Lutfi Fahrul Rizal membahas hanya sampai ke bagian kebijakan PSBB saja, belum merinci kebagian new normal. Oleh karena itu penelitian ini bermaksud melanjutkan dari beberapa penelitian sebelumnya, dikarenakan kebijakan pemerintah berganti-ganti dan memiliki dampak yang berbeda-beda pula.

Oleh karena itu, kebijakankebijakan yang telah disodorkan oleh pemerintah perlu ada kajian secara mendalam untuk meluruskan anggapananggapan yang kurang baik terhadap pemerintah. Penulis mencoba untuk mengkaji secara mendalam atas kebijakankebijakan yang selama ini ditempuh oleh pemerintah. Dalam hal ini penulis ingin mengkaji dengan melalui pandangan maqashid al-syariah agar dapat diketahui seberapa besar perlindungan dan peran pemerintah terhadap hak beragama, hak

${ }^{10}$ Hudzaifah Achmad Qotadah, "Covid19: Tinjauan Maqasid Al-Shariah Terhadap Penangguhan Pelaksanaan Ibadah Shalat Di Tempat Ibadah (Hifdz Al-Nafs Lebih Utama Dari Hifdz Al-Din?)," SALAM: Jurnal Sosial Dan Budaya Syar-I 7, no. 7 (May 25, 2020): 659-72, https://doi.org/10.15408/sjsbs.v7i7.15676.

11 Shubhan Shodiq, "Penanganan Covid19 Dalam Pendekatan Kaidah Fikih Dan Ushul Fikih (Analisis Kebijakan Pembatasan Sosial Berskala Besar Dibidang Keagamaan)," Al-Adalah: Jurnal Hukum Dan Politik Islam 5, no. 2 (July 16, 2020): 100-122, https://doi.org/10.35673/ajmpi.v5i2.743.

12 Rizal, "Persfektif Siyâsah Syar'Iyyah Tentang Darurat Negara Dalam Penanganan Pandemi Covid-19." 
hidup, hak memperoleh informasi yang benar $^{13}$, hak keturunan serta hak dalam memenuhi kebutuhan hidup yang diaktualkan ke dalam rumusan kebijakankebijakan yang diatur dalam penanganan covid-19. Karena pada dasarnya maqashid al-syariah dibutuhkan dalam perumusan Undang-Undang untuk menjadi sebuah dasar dalam pemeliharaan agama, jiwa, akal, keturunan, harta benda, dan kehormatan.

\section{B. PEMBAHASAN}

\section{Fakta Corona Virus Disease 2019 (Covid-19)}

Covid-19 merupakan penamaan yang diangkat oleh organisasi kesehatan international yakni WHO. Covid-19 merupakan virus yang dari sisi gejala sama dengan penyakit lainnya, seperti gejala demam, batuk, dan lainnya. Munculnya penyakit ini, menurut para pakar disebabkan oleh virus Severe Acute Respiratory Syndrome Coronavirus 2 (SARS-Cov-2). Virus tersebut menjadi alasan datangnya covid-19 yang memiliki ciri-ciri sama persis ketika menyerang manusia maupun hewan.

Penyakit serta virus yang menjadi penyebabnya memiliki penamaan yang berbeda, dikarenakan perbedaan proses serta tujuannya. Sisi tujuan yang pertama bahwa penamaan sebuah virus didasarkan atas struktur genetik yang dimilikinya masing tentunya untuk diketahui pencegahannya dengan melalui tes diagnostik, obat, dan vaksin. Dari sisi tujuan yang kedua penyakit (disease) dicantumkan agar para pakar dapat mendiskusikan bagaimana pencegahannya, tingkat perkembangannya, serta pengobatannya yang tepat sasaran. ${ }^{14}$

13 Doli Witro, "Maqashid Syari'ah as a Filter of Hoax through Al-Quran Perspective," Jurnal Ilmiah Al-Syir'ah 18, no. 2 (2020): 187200, https://doi.org/10.30984/jis.v18i2.1133.

14 Who.int, "Naming the Coronavirus Disease (COVID-19) and the Virus That Causes
Penyakit Covid-19 ini sebenarnya memiliki penularan yang sama dengan penyakit lainnya, sebagaimana yang diungkapkan oleh Adtyo Sesio dan tim bahwa penularan/transmisi virus paling utama antara manusia dengan manusia, seperti pada penyakit SARS-CoV-2 dapat bertransmisi melalui droplet (percikan cairan) yang dikeluarkan oleh orang saat batuk atau bersin. Penularan penyakit tersebut sepenuhnya sama yang dialami oleh penyakit covid-19, bahkan penelitian terbaru menyatakan bahwa covid-19 memungkinkan memiliki aerosol dengan alokasi waktu selama 3 jam lamanya. ${ }^{15}$ Kemudian upaya pencegahan virus tersebut untuk sementara ini pun masih belum ditemukan dengan tepat dikarenakan virus ini masih dikategorikan sebagai virus paling terbaru, pencegahan selama ini hanya terbatas untuk memutuskan mata rantai virus covid-19 saja dengan melakukan isolasi, pencegahan dini, dan cuci tangan. ${ }^{16}$

Dalam rangka untuk memutus mata rantai covid-19. Lebih lanjut dijelaskan pula langkah-langkah yang efektifnya, yakni jika tangan terlihat kotor atau memegang barang-brang orang lain dianjurkan untuk memakai handsanitizer. Tangan tidak dianjurkan untuk sering memegang bagian mata, mulut, dan hidung, bersin juga harus menggunakan etika yang baik dengan ditutup memakai tisu atau bagian baju bagian lengan kiri maupun kanan, memakai masker yang tebal, serta berjaga jarak minimal 1 meter dengan orang yang akan ditemui. ${ }^{17}$

It," 2020 ,

https://www.who.int/emergencies/diseases/novelcoronavirus-2019/technical-guidance/naming-thecoronavirus-disease-(covid-2019)-and-the-virusthat-causes-it.

15 Adityo Susilo et al., "Coronavirus Disease 2019: Tinjauan Literatur Terkini,” Jurnal Penyakit Dalam Indonesia 7, no. 1 (2020): 46, https://doi.org/10.7454/jpdi.v7i1.415.

${ }^{16}$ Susilo et al., 60-62.

17 Listiana Aziza, Adistikah Aqmarina, and Maulidiah Ihsan, Pedoman Pencegahan Dan 
Berdasarkan uraian di atas dapat digaris bawahi bahwa secara fakta covid19 ini sangatlah berbahaya yang dapat menularkan secara mudah dengan manusia yang lainnya, untuk saat ini pun pencegahan yang dianggap paling efektif hanya terbatas terhadap personality (individu) dari masing-masing orang untuk taat terhadap aturan pemerintah tentang protokol kesehatan serta kebijakankebijakan yang diatur di dalamnya seperti kebijakan Pembatasan Sosial Berskala Besar (PSBB). Artinya dari beberapa hal ini masyarakat dipaksa untuk menaati aturan-aturan tersebut guna agar menjaga bersama-sama hak hidup masyarakat secara luas.

\section{Potret Kebijakan Politik Hukum Pemerintah dalam Penanganan Covid- 19}

Politik hukum secara sederhana mengandung dua sisi yang tidak dapat dipisahkan, yakni antara politik itu sendiri dan hukum. Jika dapat dimaknai bahwa politik hukum merupakan cara atau upaya dalam rangka menjadikan hukum agar sesuai dengan cita-cita serta tujuannya. Oleh karenanya, politik hukum disini harus berlandaskan filosofis bangsa yang terdapat dalam Pancasila dan pembukaan Undang-Undang Dasar Negara Republik Indonesia Tahun $1945 .{ }^{18}$ Untuk meraih cita-cita serta tujuan hukum tersebut, maka sistem yang seharusnya digunakan merupakan sistem mengandung nilai sosial serta konsep keadilan yang saling berelaborasi. $^{19}$ Bukan kepentingan beberapa pihak saja yang memanfaatkan politik sebagai dasar perwujudan hukum

Pengendalian Coronavirus Disesase (Covid-19) (Jakarta: Kementerian Kesehatan RI, 2020), 57.

18 Siti Mahmudah, "Politik Penerapan Syari'at Islam Dalam Hukum Positif Di Indonesia (Pemikiran Mahfud MD)," Al-'Adalah 10, no. 4 (2012): 408 , https://doi.org/10.24042/adalah.v10i2.294.

${ }^{19}$ Mohammad Mahfud MD, Membangun Politik Hukum, Menegakkan Konstitusi (Jakarta: RajaGrafindo Persada, 2010), 30-32. untuk menguntungkan individu ataupun kelompok yang berkepentingan.

Dalam perkembangannya politik hukum semakin berkembang menyesuaikan dengan keadaan zaman yang semakin maju, upaya dalam pencapaian cita-cita hukum akan terus diuji seiring perkembangannya. Menurut Enny Nurbaningsih menyampaikan bahwa politik hukum sendiri dalam perkembangannya belum menemukan satu makna, masih terdapat pro dan kontra dalam penerapannya. Hal tersebut terbukti dengan kebijakan politik hukum yang diambil oleh pemerintah dalam menangani kasus covid-19 saat ini.

Kebijakan covid-19 diawali dengan dikeluarkannya Undang-Undang Nomor 6 Tahun 2018 tentang Kekarantinaan Kesehatan sebelum datangnya penyakit covid-19, dengan tujuan ketika suatu saat ada kondisi darurat nasional UndangUndang tersebut bisa dijadikan sebagai landasannya, secara lebih spesifik pertimbangan pemerintah sebagai berikut: pertama, pada hakikatnya negara harus melindungi hak-hak masyarakat secara luas khususnya penjaminan kesehatan warga negara Indonesia; kedua, perkembangan zaman yang begitu pesat memungkinkan terjadinya interaksi internasional yang tentunya beresiko terhadap terganggunya kesehatan; ketiga, Indonesia merupakan salah satu bagian dari masyarakat dunia, maka perlu sekali melakukan pencegahan dini terhadap pandemi global yang suatu saat bisa menyerang masyarakat dunia termasuk Indonesia.

Beberapa alasan di atas menjadi dasar hadirnya Undang-Undang Nomor 6 Tahun 2018 tentang Kekarantinaan Kesehatan. Alasan tersebut sebenarnya diawali dari wabah penyakit yang melanda negeri yakni Flu Burung, SARS, Ebola, MERS dan lain-lain. Wabah penyakitpenyakit itu menjadi ketakutan penduduk bumi sehingga berbondong-bondong agar wabah yang besar tersebut dapat dicegah. 
Kini dunia mengalami hal yang sama lagi yakni wabah covid-19 yang tidak disangka oleh umat manusia sebelumnya, di mana tingkat keganasan dan bahayanya lebih tinggi dibandingkan dengan virus-virus yang sebelumnya, oleh karenanya pemerintah dipaksa untuk fast respon terhadap wabah tersebut demi keselamatan masyarakat nasional dengan efektif dan efisien. $^{20}$

Berdasarkan uraian di atas menjadi bukti bahwa hadirnya Undang-Undang Kekarantinaan Kesehatan menjadi jawaban atas datangnya wabah covid-19 ini. Di sisi yang pertama, bahwa Undang-Undang tersebut menjadi langkah yang sangat tepat dan cepat, namun di sisi lain ada beberapa peran pemerintah yang masih kurang maksimal dalam penerapannya, seperti kurangnya kesiapan Alat Pelindung Diri (APD), kesiapan tempat, hingga kesiapan tenaga kesehatan yang masih minim. ${ }^{21}$ Akan tetapi hemat penulis, hal tersebut tidak secara mutlak menjadi kesalahan pemerintah, namun keadaan situasi dan kondisi yang mendadak sedangkan perlengkapan yang ada hanya terbatas. Selain itu pula, masyarakat juga kurang berpartisipasi penuh dalam penanggulangan covid-19 yang kemudian dianggap kesalahan pemerintah, sebagaimana survei yang dilakukan oleh Badan Pusat Statistik (BPS) terhadap 90.967 masih banyak masyarakat yang melanggar perintah protokol kesehatan. ${ }^{22}$ Artinya apa yang dilakukan oleh

${ }^{20}$ Rizal, "Persfektif Siyâsah Syar'Iyyah Tentang Darurat Negara Dalam Penanganan Pandemi Covid-19," 49.

21 Liputan6.com, "Pemerintah Diminta Lebih Fokus Pada Upaya Pencegahan Penyebaran Corona Covid-19,", 2020, liputan6.com/news/read/4210621/pemerintahdiminta-lebih-fokus-pada-upaya-pencegahanpenyebaran-corona-covid-19.

${ }^{22}$ Kompas.com, "Survei BPS: Masyarakat Tak Taat Protokol Kesehatan Karena Tak Ada Sanksi Tegas," 2020, https://nasional.kompas.com/read/2020/09/28/1656 0511/survei-bps-masyarakat-tak-taat-protokolkesehatan-karena-tak-ada-sanksi?page=all. pemerintah saat ini merupakan kebijakan yang terbaik.

Hadirnya Undang-Undang Nomor 6 Tahun 2018 tentang Kekarantinaan Kesehatan sebenarnya merupakan hasil politik pemerintah dalam penanganan wabah penyakit yang besar dengan tujuan dapat meminimalisir terjadinya penyebaran yang signifikan, kebijakan tersebut merupakan kewenangan dari pemerintah pusat dalam bidang pertahanan. ${ }^{23}$ Dalam hal ini pemerintah pusat harus memperhatikan potensi kerawanan dan bahaya darurat kesehatan itu sendiri, ada beberapa jenis karantina yang disebutkan dalam Undang-Undang, yakni: ${ }^{24}$ pertama, karantina rumah, darurat kesehatan yang dialami dalam lingkup satu rumah saja; kedua, karantina wilayah merupakan masyarakat wilayah yang telah didiagnosis bahwa di wilayah tersebut sudah terkonfirmasi suatu penyakit; ketiga, karantina rumah sakit merupakan karantina yang dilakukan oleh orang-orang yang memiliki keperluan di rumah sakit baik pengunjung, pasien, atau barang yang telah didiagnosis bahwa rumah sakit tersebut telah terjadi penularan penyakit; keempat, PSBB merupakan pembatasan masyarakat untuk bertemu dengan orang-orang disekitarnya dan pembatasan pergi di luar wilayahnya guna untuk meminimalisir rantai penyebaran penyakit.

Berdasarkan pernyataan di atas merupakan bentuk tanggung jawab pemerintah atas amanah Undang-Undang Nomor 6 Tahun 2018 tentang Kekarantinaan Kesehatan dalam rangka untuk mewujudkan tujuan hukum dari politik hukum itu sendiri, kemudian pemerintah menetapkan Peraturan Pemerintah Nomor 21 Tahun 2020 tentang

23 Pasal 3 huruf (c) Undang-Undang 6 Tahun 2018 tentang Kekarantinaan Kesehatan, halaman 9 Lembaran Negara Republik Indonesia Tahun 2OI8 Nomor 128.

${ }^{24}$ Pasal 49-60 Undang-Undang 6 Tahun 2018 tentang Kekarantinaan Kesehatan, halaman 31-36 Lembaran Negara Republik Indonesia Tahun 2OI8 Nomor 128. 
Pembatasan Sosial Berskala Besar yang bertujuan untuk mempercepat penanganan covid-19. Peraturan pemerintah tersebut sudah mendapat dukungan banyak pihak, khususnya Menteri Kesehatan dengan memperhatikan efektifitas dan efisiensinya, sumber daya sebagai pendukung, teknis operasional, pertimbangan politik, hukum, sosial, budaya, serta pertahanan dan keamanannya. $^{25}$

Kebijakan yang ditempuh dalam Peraturan Pemerintah (PP) berupaya untuk melindungi masyarakat sebagai prioritas utamanya dengan melihat cita-cita terbentuknya Negara ini yang tertuang dalam pembukaan konstitusi, berbunyi: ${ }^{26}$

Kemudian daripada itu untuk membentuk suatu Pemerintah Negara Indonesia yang melindungi segenap bangsa Indonesia dan seluruh tumpah darah Indonesia dan untuk memajukan kesejahteraan umum, mencerdaskan kehidupan bangsa, dan ikut melaksanakan ketertiban dunia yang berdasarkan kemerdekaan, perdamaian abadi dan keadilan sosial..."

Sebagaimana konsekuensinya bahwa penerapan PSBB ini merupakan suatu hal yang mendukung kepentingan rakyat banyak dengan memberlakukan libur sekolah dan tempat kerja, pembatasan kegiatan keagamaan, dan/atau pembatasan kegiatan di tempat atau fasilitas umum. Tentunya kebijakan tersebut dilakukan dengan dasar kepentingan banyak orang agar dapat memutuskan penyebaran mata rantai covid-19 di masyarakat, walaupun dalam aspek ekonomi kebijakan tersebut

${ }^{25}$ Pasal 2 Peraturan Pemerintah Nomor 21 Tahun 2020 tentang Pembatasan Sosial Berskala Besar Dalam Rangka Percepatan Penanganan Coronavirus Disease 2019 (Covid-19), halaman 2 Lembaran Negara Republik Indonesia Tahun $2 \mathrm{O} 2 \mathrm{O}$ Nomor 91.

26 Alinea Ke-4 Pembukaan UndangUndang Dasar Negara Republik Indonesia Tahun 1945. dinilai merugikan masyarakat bahkan negara.

Selang beberapa waktu kemudian melihat situasi dan kondisi yang berkembang, pemerintah memberikan kebijakan baru yakni era new normal merupakan suatu situasi dan kondisi yang mengharuskan masyarakat membiasakan diri dalam berperilaku sehari-hari, namun perilaku tersebut terbatas. Artinya masyarakat diperbolehkan beraktivitas seperti pada umumnya namun tetap menggunakan protokol kesehatan yang ketat sebagaimana yang diatur dalam Keputusan Menteri Kesehatan Nomor.HK.01.07/MENKES/328/2020. ${ }^{27}$

Dalam hal pendidikan misalnya para siswa dituntut untuk terbiasa belajar melalui online, dituntut menggunakan teknologi informatika dan informasi yang semakin berkembang. Dalam bidang ekonomi, dampaknya terlihat pesat masyarakat boleh saja keluar untuk berbelanja di pasar, namun tetap berbeda dengan sebelumnya mereka akan cenderung lebih memilih membeli makanan yang instan. Dalam hal sosial, masyarakat akan mulai ada jarak dalam berbicara, tidak berjabat tangan, dan lain-lain. $^{28}$

Kebijakan new normal tersebut ditempuh dengan alasan agar ekonomi, politik, pendidikan, hukum, dan lain-lain tidak semakin terpuruk, karena covid-19 tidak dapat dipastikan akan hilang dalam beberapa waktu dekat ini, sebagaimana yang diungkapkan oleh Miki Riyan selaku direktur kedaruratan WHO mengatakan bahwa corona tidak akan bisa hilang

27 Keputusan Menteri Kesehatan Nomor HK.01.07/MENKES/328/2020 tentang Panduan Pencegahan dan Pengendalian Covid-19 di Tempat Kerja Perkantoran dan Industri dalam Mendukung Keberlangsungan Usaha Pada Situasi Pandemi.

${ }_{28}$ Ida Bagus Gede Paramita and I Gede Gita Purnama Arsa Putra, "Implementasi Konsep Responsible Tourism Marketing (Rtm) Di Desa Wisata Jatimulyo Kabupaten Kulonprogo Yogyakarta," Pariwisata Budaya: Jurnal Ilmiah Pariwisata Agama Dan Budaya 5, no. 2 (2020): 58, https://doi.org/10.25078/pba.v5i2.1723. 
walaupun sudah ditemukan vaksin. ${ }^{29}$ Frasa "tidak akan hilang" ini menjadi kekhawatiran pemerintah untuk dipaksa agar membuat kebijakan baru. Kebijakan yang ditempuh pemerintah sudah sangat tepat yakni era new normal seperti yang dijelaskan sebelumnya, masyarakat dipaksa untuk berdampingan hidup dengan covid-19 agar keterpurukan ekonomi dapat stabil kembali.

\section{Pro dan Kontra Kebijakan Politik Hukum Pemerintah dalam Penanganan Covid-19}

Kebijakan-kebijakan yang ditempuh oleh pemerintah di atas tidak berjalan mulus sesuai kehendak semua masyarakat, masih terdapat banyak coretan hitam terhadap kebijakan yang ditempuh oleh pemerintah, dibuktikan dengan hasil riset Institute for Development of Economics and Finance (Indef) masih terdapat sebagian masyarakat yang tidak suka dengan kebijakan yang ditempuh oleh pemerintah dengan dalih, sebagai berikut: "pemerintah kurang berkoordinasi, tidak efektif dalam memaksimalkan anggaran yang ada, dan penanganan kasus-kasus yang kurang tepat." 30

Pernyataan tersebut didukung oleh

ILUNI (Ikatan Alumni Universitas Indonesia) menganggap bahwa pemerintah selama ini tidak efektif dalam menangani kasus-kasus covid-19, ketidakefektifan pemerintah sendiri dalam menangani covid-19 ditandai pula dengan peningkatan covid-19 yang masih terbilang tinggi. Artinya penerapan selama ini yang

29 Kompas.com, "WHO Peringatkan,

Virus Corona Tidak Akan Hilang Meski Ada Vaksin,"

2020 ,

https://www.kompas.com/sains/read/2020/05/14/12 3200923/who-peringatkan-virus-corona-tidakakan-hilang-meski-ada-vaksin?page=all.

${ }^{30}$ Zulfa Harirah MS and Annas Rizaldi, "Merespon Nalar Kebijakan Negara Dalam Menangani Pandemi Covid 19 Di Indonesia," Jurnal Ekonomi Dan Kebijakan Publik Indonesia 7, no. 1 (2020): 45 , https://doi.org/10.24815/ekapi.v7i1.17370. dilakukan oleh pemerintah masih belum memiliki nilai jera kepada masyarakat secara luas.

Namun demikian pernyataan tersebut tidak semuanya benar, sebab fakta yang ada ketidaktaatan masyarakat terhadap aturan yang dibuat oleh pemerintah bukan mutlak kesalahan pemerintah atas kebijakan-kebijakan yang telah dibuatnya, tapi bisa jadi kesadaran masyarakat terhadap penggunaan protokol kesehatan yang masih sangat rendah terutama bagi masyarakat kelas bawah (dilihat dari aspek pendidikan, ekonomi, dan sosial budayanya). ${ }^{31}$ Selain itu pula, peningkatan covid-19 tidak mutlak menjadi kesalahan pemerintah dalam membuat kebijakan tersebut, tapi karena pandemi covid-19 ini yang terlalu sulit untuk dibasmi, buktinya Amerika yang notabenya adalah negara maju namun sampai saat ini negara tersebut masih dikategorikan menjadi negara yang jumlah kasus covid-19nya paling tinggi di antara negara-negara yang lainnya. ${ }^{32}$

Dari pemaparan di atas menjadi cerminan penting bahwa rentetan kebijakan yang selama ini ditempuh oleh pemerintah tidak selalu sempurna, melainkan tetap saja memiliki beberapa point kritik agar kebijakan ke depan yang akan ditempuh dibenahi kembali dengan memprioritaskan hak-hak kesejahteraan masyarakat, sebagaimana yang telah diamanatkan dalam pembukaan konstitusi.

\section{Pandangan Maqashid Al-Syari'ah Terhadap Kebijakan Politik Penanganan Covid-19}

Dalam bahasa arti dari maqashid al-syariah adalah tujuan adanya syariah (hukum). Secara istilah diartikan sebagai ajaran pokok untuk mencapai tujuan atas ditetapkannya sebuah ketetapan. Tujuan utamanya adalah untuk memberikan kemanfaatan bagi seluruh umat manusia di

\footnotetext{
${ }^{31}$ Harirah MS and Rizaldi, 47.

${ }^{32}$ Covid19.go.id, "Data Sebaran."
} 
dunia. ${ }^{33}$ Menurut para ushul fiqh maqashid al-syari'ah dibagi menjadi 3 yakni: 1) Dharuriyat merupakan kebutuhan utama manusia atau sering disebut sebagai kebutuhan primer baik dalam konteks dunia maupun akhirat, kebutuhan tersebut dibagi lagi menjadi lima, yaitu: ${ }^{34}$ perlindungan agama (hifdzu ad-diin), perlindungan jiwa (hifdzu an-nafs), perlindungan akan (hifdzul 'aql), perlindungan keturunan (hifdzu nasl) dan perlindungan harta (hifdzul mal); 2) Hajiyat, yakni kebutuhan sekunder dan 3) Tahsiniyat, yakni kebutuhan pelengkap. ${ }^{35}$

Jika melihat konteks penanganan kebijakan covid-19 di Indonesia bahwa kebijakan selama ini sebenarnya sudah memenuhi ke-5 aspek tersebut/sudah sesuai dengan tujuan dari maqashid syariah, secara lebih spesifik sebagai berikut:

1. Pemeliharaan agama (hifdz al-dîn). Dalam pemeliharaan agama, sebagaimana Al-Ghazali dan AlSyatibi bahwa bagi manusia yang tidak menjalankan kewajiban agamanya akan diberikan sanksi atau hukuman dikarenakan melakukan tindakan pengrusakan agama. Berbeda dengan Ibn 'Asyur menyatakan bahwa pemeliharaan agama adalah kebebasan menganut kepercayaan sebagaimana implementasi dari "la ikraha fi al-

${ }^{33}$ Yubsir Yubsir, “Maqashid Al-Syari'ah Sebagai Metode Interpretasi Teks Hukum: Telaah Filsafat Hukum Islam," Al-'Adalah 11, no. 2 (2013):

241 , https://doi.org/10.24042/adalah.v11i2.265; AlSyâtibî, Al-Muwafaqât Fi Ushûl Al-Syari'ah, Jilid II (al-Qahirah: Musthafâ Muhammad, n.d.), 2-3.

34 Ade Iskandar Nasution, "Pendekatan Maqashid Al-Syari'Ah Dalam Praktik Pembiayaan Di Koperasi Peternak Sapi Bandung Utara (KPSBU) Lembang," Asy-Syari'ah 21, no. 1 (2019): 35, https://doi.org/10.15575/as.v21i1.4036.

${ }^{35}$ La Jamaa, "Dimensi Ilahi Dan Dimensi Insani Dalam Maqashid Al-Syari'ah," Asy-Syir'ah: Jurnal Ilmu Syari'ah Dan Hukum 45, no. 2 (2011): 1258 , https://doi.org/10.14421/asysyir'ah.2011.\%25x. din" artinya "tidak ada paksaan dalam agama" (Q.S. Al-Baqarah: 256). Pengertian tersebut sepaham dengan situasi dan kondisi yang saat ini melanda negeri, melihat negara Indonesia merupakan negara yang majemuk (beragam agama), masyarakat dituntut agar tetap selalu digaris agama dan menjaga toleransi satu sama lainnya ${ }^{36}$, kemudian pemerintah melindunginya dengan regulasi-regulasi yang ada. Kebijakan-kebijakan yang diambil dalam penanganan covid-19 ini menjadi cerminan yang nyata bahwa negara ingin melindungi keberagaman agama yang begitu banyak dalam negeri.

2. Pemeliharaan jiwa (hifdz al-nafs). Memelihara jiwa dalam hal ini merupakan hak setiap individu atau kelompok yang harus dijaga dan dilindungi. Perlindungan hak-hak manusia juga diatur dalam Pasal 28A-28J Undang-Undang Dasar Negara Republik Indonesia Tahun 1945 tentang hak-hak asasi manusia yang harus dilindungi dan dijaga oleh negara sebagai dasar terbentuknya aturan-aturan yang di bawahnya. ${ }^{37}$ Artinya segala aturan yang diatur oleh pemerintah dipastikan akan selalu didasari atas

${ }^{36}$ Betria Zarpina Yanti and Doli Witro, "Self Maturity and Tasamuh as a Resolution of Religious Conflicts," Intizar 25, no. 2 (2019): 8794, https://doi.org/https://doi.org/10.19109/intizar.v25i 2.5608; Betria Zarpina Yanti and Doli Witro, "Islamic Moderation as a Resolution of Different Conflicts of Religion," Andragogi: Jurnal Diklat Teknis Pendidikan Dan Keagamaan 8, no. 1 (2020): 446-57, https://doi.org/https://doi.org/10.36052/andragogi.v 8i1.127; Subhan Hi Ali Dodego and Doli Witro, "Islamic Moderation as a Solution to Prevent Radicalism and Extremism Religious in Indonesia," Dialog 43, no. 2 (2020): 199-228, https://doi.org/10.47655/dialog.v43i2.375.

${ }^{37}$ Undang-Undang Desa Negara Republik Indonesia Tahun 1945. 
perlindungan terhadap warga negara, jadi jika dihubungkan dengan kebijakan yang ambil oleh pemerintah dalam penanganan covid-19 tentunya sudah sangat mencerminkan perlindungan terhadap jiwa atau perlindungan masyarakat secara luas agar mereka tetap hidup dan tetap terjaga hakhaknya dari wabah penyakit covid19.

3. Pemeliharaan akal (hifdz al-'aql). Pada awalnya penjagaan terhadap akal dipahami sebagai perbuatan yang tidak diperbolehkan untuk merusak akal, seperti meminum khamr. Dalam pandangan Abu Zahrah konsep tersebut menjadi lebih luas, mengcover pemikiran yang ilmiah, mecegah sikap taklid, mencegah para tenaga ahli yang ingin keluar negeri agar tetap stay membangun negeri. ${ }^{38}$ Tentunya pemahaman tersebut sangat relevan untuk diterapkan dalam keadaan situasi dan kondisi saat ini untuk mencegah terjadinya taklid. Semakin meluasnya informasi yang tersebar dalam dunia maya ${ }^{39}$, semakin pula kejahatan yang berkembang apalagi kondisi dan situasi saat ini menjadi hal yang sangat wajar sekali, salah satunya adalah kejahatan ujaran kebencian dan hoaks. ${ }^{40}$ Perbuatan

38 Muhamad Abu Zahrah, Ushul Fiqih (Penerjemah) Saefullah Ma'shum, Dkk (Jakarta: PT Pustaka Firdaus, 1994), 550.

${ }^{39}$ Wiji Nurasih, Mhd. Rasidin, and Doli Witro, "Islam Dan Etika Bermedia Sosial Bagi Generasi Milenial: Telaah Surat Al-'Asr," AlMishbah: Jurnal Ilmu Dakwah Dan Komunikasi 16, no. 1 (July 9, 2020): 149-78, https://doi.org/10.24239/almishbah.Vol16.Iss1.194.

40 Doli Witro, "Peaceful Campaign in Election Al-Hujurat Verse 11 Perspective," Alfuad:Jurnal Ilmu Sosial Keagamaan 3, no. 2 (2019): 15-24, https://doi.org/http://dx.doi.org/10.31958/jsk.v3i2.1 796; Doli Witro, "Problematika Hoax Di Media Sosial: Telaah Pesan Tabayyun Dalam Surat Al- hoaks tentunya harus dihindarkan karena dapat berujung kepada pemikiran dan persepsi yang salah. ${ }^{41}$ Oleh karenanya, tindakan penghukuman bagi orang-orang yang menyebarkan berita bohong (hoax) merupakan langkah yang sangat tepat saat ini agar tidak memperburuk stabilitas politik, ekonomi, hukum, dan lain-lain.

4. Pemeliharaan keturunan (hifdz alnasl), secara sederhana bahwa pemeliharaan ini untuk melestarikan umat manusia agar turun-temurun tetap terjaga. Selain itu, menurut Abu Zahrah bahwa pemeliharaan merupakan upaya agar sikap serta mental umat Muslim tetap terjadi ke generasi selanjutnya. ${ }^{42}$ Kebijakan yang diatur pemerintah dengan menstabilkan ekonomi, pendidikan masyarakat, politik, dan lainnya merupakan upaya/langkah pemerintah dalam rangka menjaga keturunan agar tetap utuh. Artinya politik hukum yang dilakukan oleh pemerintah dalam penanganan covid-19 adalah langkah yang tepat.

5. Pemeliharaan harta (hifdz al-mâl). Menurut Al-Ghazali bahwa perlindungan terhadap harta diartikan sebagai pemberian sanksi bagi orang yang melakukan tindakan pencurian. Ruang lingkup pemaknaan diperluas oleh AlJuwaini bahwa pemeliharaan harta di dalamnya mencakup ekonomi, bantuan sosial, dan mempersempit

Hujurat/49: 6," in Proceedings of the 3rd BUAF (Borneo Undergraduate Academic Forum) (Kalimantan Tengah, Indonesia, 17-19 Oktober: Institut Agama Islam Negeri (IAIN) Palangkaraya, 2018), 183-90.

${ }^{41}$ Doli Witro, "Urgency Rijalul Posting in Preventing Hoax: Quranic Perspective," Islamic Communication Journal 5, no. 1 (2020): 38-49, https://doi.org/http://dx.doi.org/10.21580/icj.2020.5 .1.5451.

42 Zahrah, Ushul Fiqih (Penerjemah) Saefullah Ma'shum, Dkk, 551. 
jurang perbedaan kelas sosial ekonomi masyarakat. Konsep tersebut senada dengan kebijakan ekonomi yang telah diaturnya, misalnya Bank Indonesia mengurangi prosentase suku bunga tujuannya agar masyarakat berbondong-bondong dapat meminjam uang di bank, kebijakan BLT (Bantuan Langsung Tunai) agar masyarakat yang terdampak atas covid-19 dapat tetap hidup, serta kebijakan-kebijakan yang lainnya. Semua itu bertujuan agar hak-hak ekonomi rakyat tetap terjaga dengan maksimal.

Dalam kitab mulakhas manzhumah fiqhiyyah yang di ringkas oleh $\mathrm{Abu}$ Humaid Abdullah al Falasi dari kitabnya Asy Syaikh Muhammad Shalih Al Utsaimin dalam kaidah ke 20 dikatakan: "jika ada dua mudharat (bahaya) saling berhadapan maka diambil yang paling ringan". ${ }^{43}$ Teori ushul fiqh yang dijelaskan ini berhubungan sekali dengan kebijakan yang telah ditempuh oleh pemerintah, karena jika dilihat dari sisi substansinya kebijakan dari pemerintah masih kurang baik, tetapi jika kebijakan itu tidak dibuat oleh pemerintah akan lebih tidak baik lagi dan berdampak terhadap keselamatan hakhak masyarakat secara luas. Oleh karenanya, politik kebijakan yang diterapkan saat ini harus kita hargai dengan naluri yang baik, karena bagaimanapun juga pemerintah telah berusaha dengan maksimal agar hak-hak rakyat tetap menjadi prioritas utama sebagaimana yang diamanatkan dalam konstitusi.

Berdasarkan uraian di atas dapat disederhanakan bahwa kondisi darurat dalam menangani covid-19 dapat dikatakan sebagai bentuk jihad yang dilakukan bersama-sama antara pemimpin dengan rakyat. Sisi yang pertama, bahwa

43 Duski Ibrahim, Duski Ibrahim, AlQawa'id Al-Fiqhiyah (Kaidah-Kaidah Fiqh) (Palembang: CV Amanah, 2019), 101. pemerintah dipaksa untuk memberikan upaya serta solusi terhadap keterpurukan ini agar dapat tercipta kemaslahatan di tengah covid-19. Sisi yang kedua, rakyat harus taat terhadap segala aturan yang telah ditetapkannya seperti menaati protokol kesehatan. Tentunya jika dua hal tersebut saling berkolaborasi dengan baik maka situasi dan kondisi seperti ini akan berangsur-angsur semakin membaik. Oleh karenanya kebijakan selama ini yang ditempuh pemerintah dalam UndangUndang Nomor 6 Tahun 2018 tentang Kekarantinaan Kesehatan merupakan langkah baik dari pemerintah untuk menjaga maqashid al-syariah dengan maksimal.

\section{PENUTUP}

Penyakit covid-19 merupakan penyakit yang nyata dan sangat berbahaya, dalam penularannya covid-19 cenderung lebih mudah daripada penyakit yang sebelumnya. Atas kondisi tersebut menjadikan ekonomi, politik, hukum serta sosial dan budaya masyarakat berbuah secara drastis. Kebijakan yang dikeluarkan pemerintah saat ini merupakan langkah dan perhatian yang tepat, karena konsep regulasi sudah disodorkan sebelum hadirnya pandemi covid-19 dengan tujuan agar kemaslahatan umat khususnya hak hidup, hak rasa aman, dan hak kesehatan tetap terjaga dengan hadirnya regulasi tersebut. Seperti Undang-Undang Nomor 6 tahun 2018 tentang Kekarantinaan Kesehatan yang kemudian turunannya mengatur tentang PSBB serta diganti dengan kebijakan era new normal dengan melihat situasi dan kondisi yang berkembang ataupun kebijakan yang lainnya. Kebijakan-kebijakan tersebut bermuara untuk menjamin perlindungan warga Negara Indonesia yang tertuang dalam konstitusi Negara.

Penanganan wabah covid-19 sudah sesuai dengan 5 indikator dari maqashid alsyari'ah, di mana kebijakan-kebijakan tersebut bertujuan untuk melindungi 
keberagaman agama masyarakat, hak untuk hidup, hak untuk menjaga pemikiran dari yang salah seperti hoaks, hak dalam melindungi keturunan, serta hak dalam menjaga kondisi ekonomi masyarakat. Dari beberapa indikator tersebut membuktikan bahwa kebijakan yang selama ditempuh oleh pemerintah sudah sesuai dengan 5 indikator maqashid alsyariah.

\section{Daftar Pustaka}

Al-Syâtibî. Al-Muwafaqât Fi Ushûl AlSyari'ah, Jilid II. al-Qahirah: Musthafâ Muhammad, n.d.

Aziza, Listiana, Adistikah Aqmarina, and Maulidiah Ihsan. Pedoman Pencegahan Dan Pengendalian Coronavirus Disesase (Covid-19). Jakarta: Kementerian Kesehatan RI, 2020.

Cnbcindonesia.com. "Kasus COVID-19 Meningkat, Ini Desakan ILUNI UI Ke Pemerintah," 2020. https://www.cnbcindonesia.com/ne ws/20201107114532-4-

200050/kasus-covid-19-meningkatini-desakan-iluni-ui-ke-pemerintah.

Covid19.go.id. "Data Sebaran," 2020. https://covid19.go.id/.

Dodego, Subhan Hi Ali, and Doli Witro. "Islamic Moderation as a Solution to Prevent Radicalism and Extremism Religious in Indonesia." Dialog 43, no. 2 (2020): 199-228. https://doi.org/10.47655/dialog.v43 i2.375.

Harirah MS, Zulfa, and Annas Rizaldi. "Merespon Nalar Kebijakan Negara Dalam Menangani Pandemi Covid 19 Di Indonesia." Jurnal Ekonomi Dan Kebijakan Publik Indonesia 7, no. 1 (2020): 36-53. https://doi.org/10.24815/ekapi.v7i1 .17370 .

Ibrahim, Duski. Duski Ibrahim, AlQawa'id Al-Fiqhiyah (KaidahKaidah Fiqh). Palembang: CV Amanah, 2019.
Jamaa, La. "Dimensi Ilahi Dan Dimensi Insani Dalam Maqashid AlSyari'ah." Asy-Syir'ah: Jurnal Ilmu Syari'ah Dan Hukum 45, no. 2 (2011):

$1253-68$.

https://doi.org/10.14421/asy-

syir'ah.2011.\%25x.

Kementerian Kesehatan RI. Pedoman Pencegahan Dan Pengendalian Coronavirus Disease (Covid-19). Jakarta: Kemenkes RI, 2020.

Kompas.com. "Survei BPS: Masyarakat Tak Taat Protokol Kesehatan Karena Tak Ada Sanksi Tegas," 2020.

https://nasional.kompas.com/read/2 020/09/28/16560511/survei-bpsmasyarakat-tak-taat-protokolkesehatan-karena-tak-adasanksi? page $=$ all.

"WHO Peringatkan, Virus Corona Tidak Akan Hilang Meski Ada Vaksin," 2020. https://www.kompas.com/sains/rea d/2020/05/14/123200923/whoperingatkan-virus-corona-tidakakan-hilang-meski-adavaksin?page $=$ all.

Kompas.id. "Upaya Dan Kebijakan Pemerintah Indonesia Menangani Pandemi Covid-19," 2020. https://kompaspedia.kompas.id/bac a/paparan-topik/upaya-dankebijakan-pemerintah-indonesiamenangani-pandemi-covid-19.

Liputan6.com. "Pemerintah Diminta Lebih Fokus Pada Upaya Pencegahan Penyebaran Corona Covid-19," 2020.

liputan6.com/news/read/4210621/p emerintah-diminta-lebih-fokuspada-upaya-pencegahanpenyebaran-corona-covid-19.

Mahfud MD, Mohammad. Membangun Politik Hukum, Menegakkan Konstitusi. Jakarta: RajaGrafindo Persada, 2010.

Mahmudah, Siti. "Politik Penerapan Syari'at Islam Dalam Hukum 
Positif Di Indonesia (Pemikiran Mahfud MD)." Al-'Adalah 10, no. 4 (2012): 403-14. https://doi.org/10.24042/adalah.v10 i2.294.

Nasution, Ade Iskandar. "Pendekatan Maqashid Al-Syari'Ah Dalam Praktik Pembiayaan Di Koperasi Peternak Sapi Bandung Utara (KPSBU) Lembang." Asy-Syari'ah 21, no. 1 (2019): 31-38. https://doi.org/10.15575/as.v21i1.4 036.

Nurasih, Wiji, Mhd. Rasidin, and Doli Witro. "Islam Dan Etika Bermedia Sosial Bagi Generasi Milenial: Telaah Surat Al-'Asr." $A l$ Mishbah: Jurnal Ilmu Dakwah Dan Komunikasi 16, no. 1 (July 9, 2020): 149-78. https://doi.org/10.24239/almishbah.Vol16.Iss1.194.

Paramita, Ida Bagus Gede, and I Gede Gita Purnama Arsa Putra. "Implementasi Konsep Responsible Tourism Marketing (Rtm) Di Desa Wisata Jatimulyo Kabupaten Kulonprogo Yogyakarta." Pariwisata Budaya: Jurnal Ilmiah Pariwisata Agama Dan Budaya 5, no. 2 (2020): 57-65. https://doi.org/10.25078/pba.v5i2.1 723.

Qotadah, Hudzaifah Achmad. "Covid-19: Tinjauan Maqasid Al-Shariah Terhadap Penangguhan Pelaksanaan Ibadah Shalat Di Tempat Ibadah (Hifdz Al-Nafs Lebih Utama Dari Hifdz Al-Din?).” SALAM: Jurnal Sosial Dan Budaya Syar-I 7, no. 7 (May 25, 2020): 659-72.

https://doi.org/10.15408/sjsbs.v7i7. 15676.

Rizal, Lutfi Fahrul. "Persfektif Siyâsah Syar'Iyyah Tentang Darurat Negara Dalam Penanganan Pandemi Covid-19." ADLIYA: Jurnal Hukum Dan Kemanusiaan
14, no. 1 (2020): 41-64. https://doi.org/10.15575/adliya.v14 i1.8404.

Shodiq, Shubhan. "Penanganan Covid-19 Dalam Pendekatan Kaidah Fikih Dan Ushul Fikih (Analisis Kebijakan Pembatasan Sosial Berskala Besar Dibidang Keagamaan)." Al-Adalah: Jurnal Hukum Dan Politik Islam 5, no. 2 (July 16, 2020): 100-122. https://doi.org/10.35673/ajmpi.v5i2 .743 .

Susilo, Adityo, Cleopas Martin Rumende, Ceva Wicaksono Pitoyo, Widayat Djoko Santoso, Mira Yulianti, Herikurniawan Herikurniawan, Robert Sinto, et al. "Coronavirus Disease 2019: Tinjauan Literatur Terkini." Jurnal Penyakit Dalam Indonesia 7, no. 1 (2020): 45-67. https://doi.org/10.7454/jpdi.v7i1.41 5.

Who.int. "Naming the Coronavirus Disease (COVID-19) and the Virus That Causes It," 2020. https://www.who.int/emergencies/d iseases/novel-coronavirus2019/technical-guidance/namingthe-coronavirus-disease-(covid2019)-and-the-virus-that-causes-it.

Witro, Doli. 'Maqashid Syari'ah as a Filter of Hoax through Al-Quran Perspective." Jurnal Ilmiah AlSyir'ah 18, no. 2 (2020): 187-200. https://doi.org/10.30984/jis.v18i2.1 133.

"Peaceful Campaign in Election Al-Hujurat Verse 11 Perspective." Alfuad:Jurnal Ilmu Sosial Keagamaan 3, no. 2 (2019): 15-24. https://doi.org/http://dx.doi.org/10. 31958/jsk.v3i2.1796.

"Problematika Hoax Di Media Sosial: Telaah Pesan Tabayyun Dalam Surat Al-Hujurat/49: 6." In Proceedings of the 3rd BUAF (Borneo Undergraduate Academic Forum), 183-90. Kalimantan 
Tengah, Indonesia, 17-19 Oktober: Institut Agama Islam Negeri (IAIN) Palangkaraya, 2018.

-. "Urgency Rijalul Posting in Preventing Hoax: Quranic Perspective." Islamic Communication Journal 5, no. 1 (2020): $\quad 38-49$. https://doi.org/http://dx.doi.org/10. 21580/icj.2020.5.1.5451.

Yanti, Betria Zarpina, and Doli Witro. "Islamic Moderation as a Resolution of Different Conflicts of Religion." Andragogi: Jurnal Diklat Teknis Pendidikan Dan Keagamaan 8, no. 1 (2020): 44657.

https://doi.org/https://doi.org/10.36 052/andragogi.v8i1.127.

—. "Self Maturity and Tasamuh as a Resolution of Religious Conflicts." Intizar 25, no. 2 (2019): 87-94. https://doi.org/https://doi.org/10.19 109/intizar.v25i2.5608.

Yubsir, Yubsir. "Maqashid Al-Syari'ah Sebagai Metode Interpretasi Teks Hukum: Telaah Filsafat Hukum Islam." Al-'Adalah 11, no. 2 (2013): 241-48. https://doi.org/10.24042/adalah.v11 i2.265.

Zahrah, Muhamad Abu. Ushul Fiqih (Penerjemah) Saefullah Ma'shum, Dkk. Jakarta: PT Pustaka Firdaus, 1994. 